\title{
TSH receptor antibodies have predictive value for breast cancer - retrospective analysis
}

Paweł Szychta ${ }^{1,4}$, Wojciech Szychta ${ }^{1,5}$, Adam Gesing ${ }^{1}$, Andrzej Lewiński ${ }^{2,3}$ and Małgorzata Karbownik-Lewińska ${ }^{1,3^{*}}$

\begin{abstract}
Background: Associations between breast cancer and thyroid disorders are reported in numerous studies. Relationships between thyroperoxidase antibodies (TPOAb), thyroglobulin antibodies (TgAb) and breast cancer have been previously demonstrated. However, no analysis has been performed concerning an association between thyrotropin (TSH) receptor antibodies (TSHRAb) and breast cancer. The aim of the study was to evaluate the prevalence of breast cancer or benign breast tumors in patients with Graves' disease and to analyze a possible relationship between Graves' disease and these two groups of breast diseases with emphasis to epidemiology and laboratory findings.

Patients and methods: Clinical and laboratory details of 2003 women hospitalized for endocrine disorders were retrospectively analyzed, using an unpaired Student's $t$-test, logistic regression analysis, $X^{2}$ test of independence or the two-sided ratio comparison test.

Results: The coexistence of Graves' disease and breast cancer was statistically significant. We observed TSHRAb and $\operatorname{TgAb}$ more frequently in patients with breast cancer. We found that TSHRAb is the only variable possessing predictive value for breast cancer.

Conclusions: The strong relationship between Graves' disease and breast cancer is proposed. We suggest that TSHRAb could be described as a positive determinant of breast cancer. The present data call attention to the usefulness of screening for breast cancer in long-term follow-up of patients with autoimmune thyroid disorders, especially of those with Graves' disease. Similarly, screening for autoimmune thyroid disorders should be performed in patients with nodular breast disease. Additionally, the article draws ideas for further research in order to develop targeted treatment for more successful outcome in patients with breast cancer.
\end{abstract}

Keywords: Breast cancer, Thyroid, Autoimmune disease, Graves' disease, TSH receptor antibody, TSH, Thyroglobulin antibody, Thyroperoxidase antibody

\section{Introduction}

Breast cancer is a hormone dependent malignancy. Thyroid hormone receptors affect both the normal breast cell differentiation and breast cancer cell proliferation, with effects of thyroid hormones similar to those caused by estrogens [1,2]. Relationship between thyroid diseases, such as nodular hyperplasia, hyperthyroidism and thyroid cancer, with breast cancer was demonstrated in several studies [3-6]. However, ambiguous results concerning the

\footnotetext{
* Correspondence: MKarbownik@hotmail.com

'Department of Oncological Endocrinology, Medical University of Lodz, 7/9

Zeligowski St., 90-752, Lodz, Poland

${ }^{3}$ Department of Endocrinology and Metabolic Diseases, Polish Mother's

Memorial Hospital, Research Institute, Lodz, Poland

Full list of author information is available at the end of the article
}

above association have been recently summarized [7]. In contrast, hypothyroidism due to Hashimoto's thyroiditis was documented as a protective factor against breast cancer [8-10], but also this observation was not confirmed in other sources [11].

Graves' disease, one of the thyroid autoimmune diseases, is characterized - in its typical form - by hyperthyroidism with laboratory results of decreased thyrotropin (TSH) level, increased free thyroxine $\left(\mathrm{FT}_{4}\right)$ and/or free triiodothyronine $\left(\mathrm{FT}_{3}\right)$ levels, detectable TSH receptor (TSHR) stimulating antibodies (TSHRAb), usually positive thyroid peroxidase antibodies (TPOAb) and thyroglobulin antibodies $(\mathrm{TgAb})$ [12]. An exclusive diagnostic feature of Graves' disease is the presence of TSHRAb. The ligand 
for TSHRAb, i.e. TSHR, is also present in breast cancer tissue [13].

Only limited aspects of potential association between Graves' disease and breast cancer have been postulated $[14,15]$, whereas the exact mechanism has not been identified [16]. Genetic, environmental and molecular pathways of both female predominant diseases have been described, and integrated analysis of the above entities provides opportunity to identify the potential relevant common etiological mechanisms [17]. The potential relationship between antithyroid autoantibodies and breast cancer has not been clearly documented, as the elevated serum levels of TPOAb and TgAb in patients with breast cancer, detected in some studies [18-21], have not been confirmed elsewhere [22,23]. Moreover, no conclusive research has been undertaken concerning significance of TSHRAb in patients with breast cancer [24].

The aim of the study was to evaluate the prevalence of breast cancer or benign breast tumors in patients with Graves' disease and to analyze a possible relationship between Graves' disease and these two groups of breast diseases with emphasis to epidemiology and laboratory findings.

\section{Patients and methods}

Retrospective clinical details of 2003 women, who were hospitalized for endocrine disorders in the Department of Endocrinology and Metabolic Diseases at the Polish Mother's Memorial Hospital - Research Institute in Lodz within a 3-year period between 2002 and 2005, were retrieved from the hospital records following the internal audit approval. Inclusion criteria were female adults. Exclusion criteria were all oncological conditions other than breast neoplasia and thyroid disorders other than Graves' disease, such as nodular goiter, thyroid cancer, autoimmune thyroiditis (AIT), etc.

After exclusion, 1686 women aged $36.48 \pm 15.95$ years were enrolled to the study (Table 1). Two studied groups consisted of 47 patients with benign breast tumors (BBT), aged $46.27 \pm 14.18$ years and 9 patients with breast cancer $(\mathrm{BC})$, aged $54.55 \pm 9.60$ years. Therefore, 1630 women hospitalized for several non-oncological diseases and without thyroid diseases other than Graves' disease (polycystic ovary syndrome, primary infertility, osteopenia, osteoporosis, obesity, dwarfism, anorexia, atherosclerosis, cardiomyopathy, dyslipidemia, hirsutism, hypertension, ischemic heart disease, gastric ulcer, metabolic syndrome or diabetes of any type) were considered as a control group (C) with an average age of $36.10 \pm$ 15.89 years.

Because of the relatively high age range of women with breast cancer and to analyze the cause-effect relation, age-matched groups of patients and healthy women could not be investigated in all stages of the analysis. Therefore, the predictors of breast cancer were analyzed in the age-matched group of 499 patients, including 9 patients with $\mathrm{BC}$ aged $54.55 \pm 9.60$ years and 490 control individuals $(\mathrm{C})$ aged $53.86 \pm 8.88$ years $(\mathrm{p}>0.05)$.

The following parameters were recorded with the use of the data analysis program, designed by one of co-authors of the study (P.S.): age and laboratory parameters, i.e. TSH, $\mathrm{FT}_{4}, \mathrm{FT}_{3}, \mathrm{TSHRAb}, \mathrm{TgAb}$ and TPOAb. The following diagnoses were considered: Graves' disease, benign breast tumors (BBT) and breast cancer (BC). The normal ranges of the laboratory tests in our hospital are: TSH (0.27-4.2 $\mathrm{mIU} / \mathrm{L}), \mathrm{FT}_{4}(0.93-1.7 \mathrm{ng} / \mathrm{dL}), \mathrm{FT}_{3}(1.8-4.6 \mathrm{pg} / \mathrm{mL})$, TPOAb $(<35 \mathrm{IU} / \mathrm{mL}), \mathrm{TgAb}(<115 \mathrm{IU} / \mathrm{mL})$ and TSHRAb $(<1.8 \mathrm{IU} / \mathrm{mL})$.

The data were statistically analyzed using an unpaired Student's $t$-test - for continuous variables. The two-sided ratio comparison test was used to evaluate the frequency of events. Univariate logistic regression analysis, followed by multivariate logistic regression analysis, was used to determine which continuous variable might have predicted breast cancer or benign breast tumors. The $\chi 2$ test of independence was used to determine, which dichotomized variable might have predicted breast cancer or benign breast tumors. The results are presented as mean \pm standard deviation (SD). Statistical significance was determined at the level of $\mathrm{p}<0.05$.

\section{Results}

Statistically significant differences were found in age distribution between patients with breast cancer (BC) and control group $(C)$, as well as between women with benign breast tumors (BBT) and control group (C) (Table 1). However, there were no statistical differences

Table 1 Clinical characteristics of patients with breast cancer, benign breast tumors, Graves' disease and in controls

\begin{tabular}{|c|c|c|c|c|c|c|c|}
\hline \multirow[t]{2}{*}{ Parameter } & \multicolumn{4}{|c|}{ Clinical characteristics } & \multicolumn{3}{|c|}{ Statistical analysis } \\
\hline & $\mathrm{BC}$ & BBT & $\mathrm{C}$ & All patients & $p(B C$ vs. BBT) & $p(B C$ vs. $C)$ & p (BBT vs. C) \\
\hline Patients - No (\%) & $9(0.53 \%)$ & $47(2.78 \%)$ & $1630(96.6 \%)$ & $1686(100 \%)$ & ns & $<0.0001$ & $<0.0001$ \\
\hline Age - yr $($ mean $\pm S D)$ & $54.55 \pm 9.60$ & $46.27 \pm 14.18$ & $36.10 \pm 15.89$ & $36.48 \pm 15.95$ & ns & 0.0005 & $<0.0001$ \\
\hline Graves' disease - No (\%) & $3(33.3 \%)$ & $6(12.7 \%)$ & $111(6.8 \%)$ & $120(7.1 \%)$ & ns & 0.0025 & ns \\
\hline
\end{tabular}

Clinical characteristics of patients with breast cancer (BC), patients with benign breast tumors (BBT) and controls (C) and the occurrence of Graves' disease. Statistical evaluation was done by an unpaired Student's $t$-test (for age) or by the two-sided ratio comparison test (for no. of patients and for Graves' disease occurrence); ns, non-significant. 
Table 2 Graves' disease as the dichotomized determinant of breast cancer or benign breast tumors

\begin{tabular}{|c|c|c|c|c|}
\hline \multirow{2}{*}{$\begin{array}{l}\text { Dichotomized } \\
\text { determinant }\end{array}$} & \multicolumn{2}{|c|}{ Association with BC $(n=9)$} & \multicolumn{2}{|c|}{ Association with BBT $(n=47)$} \\
\hline & $x^{2}$ & $p$ & $x^{2}$ & $\mathrm{p}$ \\
\hline Graves' disease $(n=120)$ & 9.41 & 0.0021 & 2.33 & ns \\
\hline
\end{tabular}

$x^{2}$ test of independence analysis of the dichotomized determinant (i.e. Graves' disease occurrence) of breast cancer (BC) or of benign breast tumors (BBT), performed in all patients; ns, non-significant in all patients.

in age distribution between patients with benign breast tumors (BBT) and patients with breast cancer (BC).

Graves' disease was diagnosed on the basis of clinical findings and the presence of TSHRAb in 120 (7.11\%) female patients aged $41.65 \pm 15.19$ years. Graves' disease coexisted more frequently with breast cancer $(p=0.0021)$, but not with benign breast tumors $(\mathrm{p}>0.05)$ (Table 2).

In breast cancer patients, the mean values for TSH were $1.724 \pm 3.629 \mathrm{mU} / \mathrm{L}$ and they did not differ significantly from those in controls $(2.12 \pm 5.41 \mathrm{mU} / \mathrm{L})$ and from those in patients with benign breast tumors $(1.35 \pm 0.89 \mathrm{mU} / \mathrm{L})$ (Figure 1). In turn, $\mathrm{FT}_{4}$ was $1.283 \pm 0.427 \mathrm{ng} / \mathrm{dL}$ in patients with breast cancer and did not differ significantly from levels found either in controls $(1.34 \pm 1.93 \mathrm{ng} / \mathrm{dL})$ or in women with benign breast tumors $(1.30 \pm 0.67 \mathrm{ng} / \mathrm{dL})$. In patients with breast cancer, $\mathrm{FT}_{3}$ was $2.882 \pm 1.617 \mathrm{pg} / \mathrm{mL}$ and was similar to controls $(3.33 \pm 1.91 \mathrm{pg} / \mathrm{mL})$ and to patients with benign breast tumors $(3.54 \pm 1.65 \mathrm{pg} / \mathrm{mL})$.

When levels of thyroid antibodies were compared among three groups of patients, the following differences were found. The mean values of serum TSHRAb were $25.65 \pm 20.29 \mathrm{IU} / \mathrm{ml}$ in breast cancer patients, they were significantly lower in controls $(4.83 \pm 8.19 \mathrm{IU} / \mathrm{ml}, \mathrm{p}=$ $0.0006)$, and were lower in patients with benign breast tumors $(8.52 \pm 14.04 \mathrm{IU} / \mathrm{ml})$, but the differences between $\mathrm{BC}$ and $\mathrm{BBT}$ or between $\mathrm{BBT}$ and controls did not reach statistical significance (Figure 2). Serum concentrations

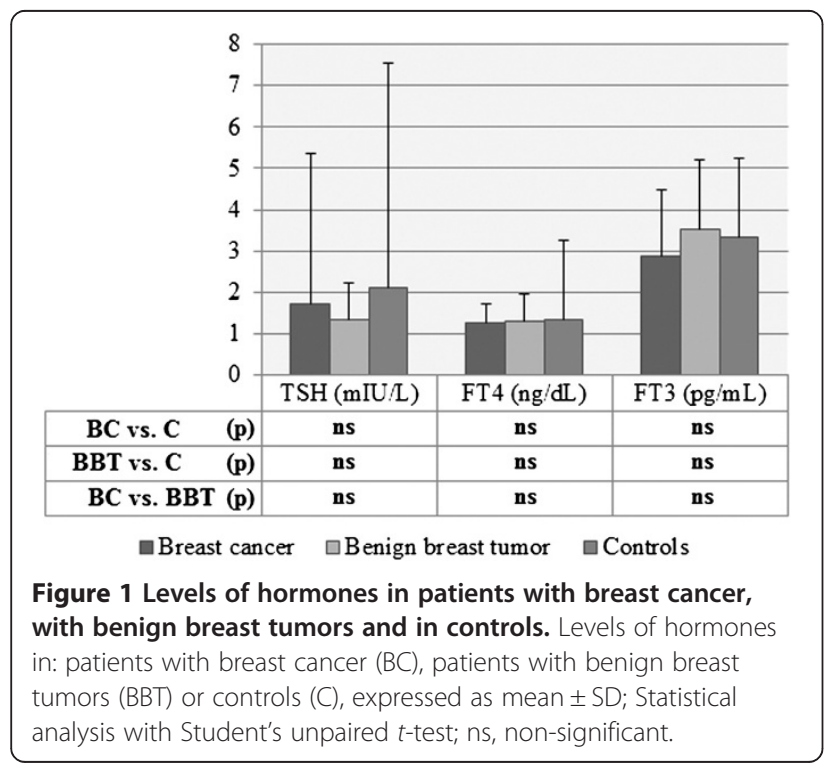

of $\operatorname{TgAb}$ in patients with breast cancer were $1120.8 \pm$ $1914.9 \mathrm{IU} / \mathrm{ml}$ and were considerably higher than in controls $(241.4 \pm 565.0 \mathrm{IU} / \mathrm{ml}, \mathrm{p}=0.0100)$ and markedly higher than in patients with benign breast tumors $(191.7 \pm 267.1 \mathrm{IU} / \mathrm{ml}, \mathrm{p}=0.0443)$ (Figure 3). In turn, TPOAb in patients with breast cancer were at level of $157.8 \pm 294.8 \mathrm{IU} / \mathrm{ml}$ and were similar to control group $(135.7 \pm 206.0 \mathrm{IU} / \mathrm{ml}, \mathrm{p}>0.05)$ and to benign breast tumors $(178.9 \pm 221.9, \mathrm{p}>0.05)$.

Several parameters, such as hormones and antibodies concentrations were submitted to a univariate and a multivariate logistic regression model. The purpose of the model was to determine which of those continuous variables might predict breast cancer or benign breast tumors either in the entire group of female patients or in age-matched groups. No predictive value for any of the examined hormones and for TPOAb was documented at univariate regression analysis in the entire group of patients (Table 3). In opposite, breast cancer predictive value for TSHRAb $(\mathrm{OR}=1.10,95 \% \mathrm{CI}=1.01-1.20$, $\mathrm{p}=0.0222)$ and $\operatorname{TgAb}(\mathrm{OR}=1.00,95 \% \mathrm{CI}=1.00-1.01, \mathrm{p}=$ 0.0377 ) was found at univariate regression analysis in the entire group of patients. Thus, TSHRAb and TgAb could be theoretically considered as positive risk factors for breast cancer. However, both above determinants lost their predictive value at multivariate analysis. In turn, meticulous logistic regression analysis, based on the age-matched

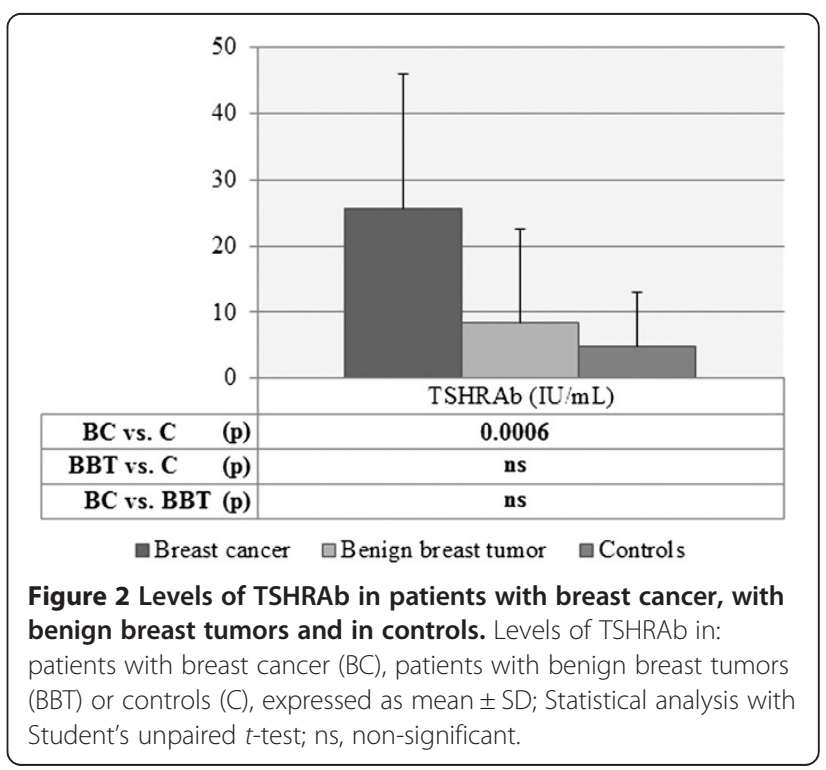




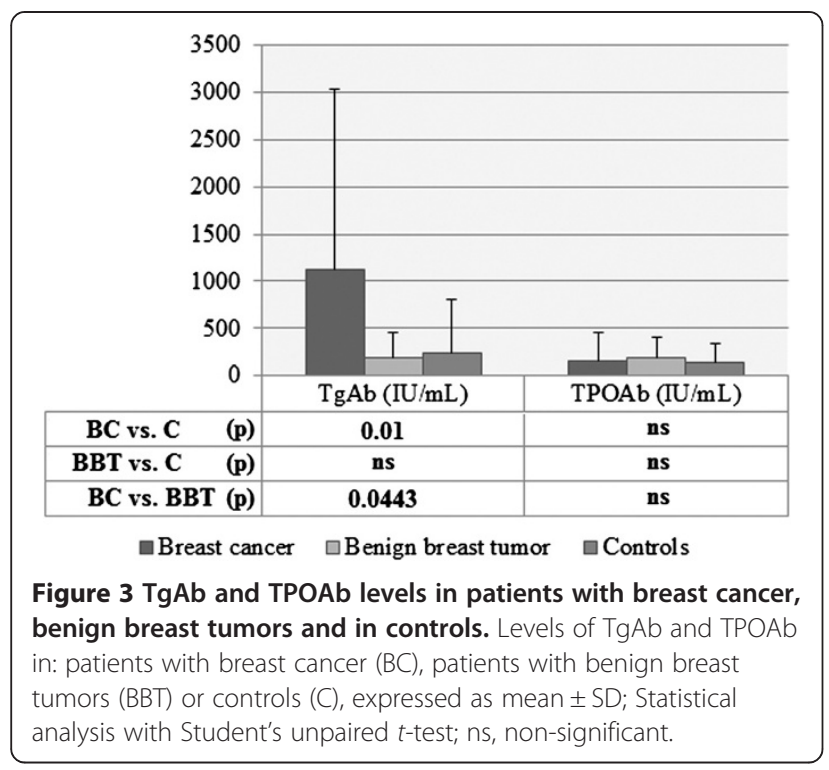

groups of patients with breast cancer and controls, revealed that TSHRAb is the only variable possessing predictive value for breast cancer $(\mathrm{OR}=1.09,95 \% \mathrm{CI}=$ $1.00-1.20, \mathrm{p}=0.0368$ ) (Table 4). No other predictors of breast cancer or benign breast tumors were documented in our series.

Distribution of breast tumors in relation to age intervals and in comparison to Graves' disease is presented in Figure 4. A shift between diagnosis of Graves' disease and breast cancer was observed. Peak incidence of Graves' disease was seen in patients at age of about 35 years and the lowest frequency was observed at age of about 45 years, whereas peak level of breast cancer diagnosis were noted at about 65 years, and the lowest frequency at about 75 years. In contrast, we observed no similar distribution trends in relation to age intervals between benign breast tumors and breast cancers or between benign breast tumors and Graves' disease.

\section{Discussion}

Mammary gland is derived from iodide-concentrating ectoderm [17]. Breast functions are similar to the thyroid gland in relation to the absorption capacity of iodide for use as a milk ingredient during lactation [4,25]. Altered thyroid hormonal function due to abnormal iodine uptake has an impact on incidence of iodine deficiency disorders (IDD) [25], autoimmune diseases and could possibly affect cancer development. Increased intake of iodine is considered as a protective factor against the occurrence of breast cancer [26]. In conformity, low levels of iodine were described in the breast cancer tissues as compared to normal breast tissue or benign breast tumors [27].

Uptake of serum iodide into the breast alveolar and ductular cells happens in the mechanism of active transport via the glycoprotein - Na+/I-symporter (NIS) [28]. The expression of NIS occurs in $80 \%$ to $90 \%$ of breast cancer cases and, thus, symporter could be potentially used in the radioisotope breast imaging with ${ }^{125} \mathrm{I}$ (alternatively ${ }^{99} \mathrm{mTc}$ ) and in the breast cancer treatment with ${ }^{131} \mathrm{I}$ (alternatively ${ }^{188} \mathrm{Re}$ ) [13], following administration of stimulants enhancing NIS expression $[29,30]$.

Assessment of hormonal thyroid function in breast cancer patients was assessed in our study with measurement of TSH, $\mathrm{FT}_{4}$ and $\mathrm{FT}_{3}$ levels and we found no differences among breast cancer patients, women with benign breast tumors and female controls. However, limited short-term hormone observations cannot be interpreted in relation to the long-term cancer development because of the changeable thyroid activity affected by several extrinsic and intrinsic factors. In turn, concerning the impact of autoimmune diseases on breast cancer incidence, we confirmed the high prevalence of breast cancer in patients with Graves' disease (Table 2).

Thyroid antibodies in the autoimmune thyroid disorders could interact with the receptors on breast tumors and thus they were previously designated as precursors for the coincidence of mammary and thyroid disorders [31]. Autoantigens, TPO in the thyroid and lactoperoxidases in

Table 3 Hormone and autoantibody concentrations as determinants of breast cancer or benign breast tumors

\begin{tabular}{|c|c|c|c|c|c|c|c|c|c|}
\hline \multirow[t]{3}{*}{ Parameter } & \multicolumn{6}{|c|}{ Association with $B C(n=9)$} & \multirow{2}{*}{\multicolumn{3}{|c|}{$\begin{array}{l}\text { Association with BBT }(n=47) \\
\text { Univariate logistic regression }\end{array}$}} \\
\hline & \multicolumn{3}{|c|}{ Univariate logistic regression } & \multicolumn{3}{|c|}{ Multivariate logistic regression } & & & \\
\hline & OR & $95 \% \mathrm{Cl}$ & $\mathrm{p}$ & OR & $95 \% \mathrm{Cl}$ & $\mathrm{p}$ & OR & $95 \% \mathrm{Cl}$ & $p$ \\
\hline TSH (mIU/L) & 0.97 & $0.75-1.26$ & ns & & - & & 1.20 & $0.92-1.55$ & ns \\
\hline $\mathrm{FT}_{4}(\mathrm{ng} / \mathrm{dL})$ & 0.96 & $0.42-2.21$ & ns & & & & 1.01 & $0.78-1.31$ & ns \\
\hline $\mathrm{FT}_{3}(\mathrm{pg} / \mathrm{mL})$ & 0.48 & $0.71-1.82$ & ns & & & & 0.95 & $0.81-1.11$ & ns \\
\hline TSHRAb (IU/mL) & 1.10 & $1.01-1.20$ & 0.0222 & 0.92 & $0.66-1.28$ & ns & 0.97 & $0.91-1.03$ & ns \\
\hline $\operatorname{TgAb}(I U / m L)$ & 1.00 & $1.00-1.01$ & 0.0377 & 0.99 & $0.99-1.00$ & ns & 1.00 & $0.99-1.00$ & ns \\
\hline TPOAb (IU/mL) & 1.00 & $0.99-1.01$ & ns & & - & & 1.00 & 0.99-1.00 & ns \\
\hline
\end{tabular}

Univariate and multivariate logistic regression analysis of the univariate determinants (such as hormone and autoantibody concentrations) of breast cancer (BC) or breast benign tumor (BBT), performed in all patients $(n=1686)$; OR, odds ratio; $C l$, confidence interval; ns, non-significant. 
Table 4 Hormone and autoantibody concentrations as breast cancer or benign breast tumors determinants, in age-matched groups

\begin{tabular}{|c|c|c|c|}
\hline \multirow[t]{2}{*}{ Parameter } & \multicolumn{3}{|c|}{ Association with $B C(n=9)$} \\
\hline & OR & $95 \% \mathrm{Cl}$ & $\mathrm{p}$ \\
\hline TSH (mIU/L) & 0.96 & $0.77-1.21$ & ns \\
\hline $\mathrm{FT}_{4}(\mathrm{ng} / \mathrm{dL})$ & 0.92 & $0.32-2.67$ & ns \\
\hline $\mathrm{FT}_{3}(\mathrm{pg} / \mathrm{mL})$ & 0.69 & $0.29-1.62$ & ns \\
\hline TSHRAb (IU/mL) & 1.09 & $1.00-1.20$ & 0.0368 \\
\hline $\operatorname{TgAb}(\mathrm{IU} / \mathrm{mL})$ & 1.00 & $0.99-1.00$ & ns \\
\hline TPOAb (IU/mL) & 0.99 & $0.99-1.00$ & ns \\
\hline
\end{tabular}

Univariate logistic regression analysis of the univariate determinants (such as hormone and autoantibody concentrations) of breast cancer (BC) or breast benign tumor (BBT), performed in the age-matched groups of patients $(n=499) ; O R$, odds ratio; $\mathrm{Cl}$, confidence interval; $n s$, non-significant.

the breast, are required for organification of iodine to produce iodoproteins [32], as they catalyze $\mathrm{H}_{2} \mathrm{O}_{2}$ production to oxidize $\mathrm{I}^{-}$[33]. Previously reported potential association between TPOAb or TgAb and breast cancer was arguable and the results were summarized in Table 5 [4,18,34-36]. The presence of TPOAb was previously described as a prognostic index of a more favorable outcome in patients with breast cancer, with similar importance to the tumor size and to the axillary nodal status [37]. In our study, TPOAb levels were similar among the three analyzed groups. In turn, $\mathrm{TgAb}$ levels were higher in our series in patients with breast cancer comparing to controls and to patients with benign breast tumors. However, the ligand for $\operatorname{TgAb}$, thyroglobulin $(\mathrm{Tg})$, has antigenicity affected by the iodine content within the protein $[18,38]$, and thus $\mathrm{TgAb}$ are present non-specifically in different diseases coexisting with the altered iodine intake [39]. More importantly, $\operatorname{TgAb}$ can be also found in patients with chronic disorders not involving thyroid [40] or even in healthy patients without any thyroid disease [41]. Thus, clinical impact of the elevated concentrations of $\mathrm{TgAb}$ is unreliable, as they were detected non-specifically to thyroid diseases or breast cancer.

Relationship between incidence of benign breast tumors and thyroid diseases with the increased levels of $\mathrm{TgAb}$ and TPOAb in serum has been also proposed [42]. Previous report documented the increased level of TPOAb in $28 \%$ of women with benign fibrocystic mastopathies and $80 \%$ had thyroid hypertrophy $[21,43]$. In contrary, we did not observe any association between Graves' disease, hormones or antibodies concentrations and occurrence of benign breast tumors.

Interaction between thyroid and breast cancer can occur in the mechanism involving TSHR, common in the adipose breast tissue [35]. Under physiological conditions, TSH via TSHR stimulates growth, differentiation and function of the thyroid cells $[4,44]$. This receptor is a target for THSRAb in Graves' disease. It should be stressed that TSHR expression is common in breast cancer, with higher prevalence in low-grade breast cancer [13]. The clinical significance of the serum TSHRAb in relation to breast cancer and Graves' disease was unresolved in the previous observations $[6,15]$. In our study, TSHRAb levels were significantly higher in breast cancer comparing to controls. They were positive determinants of breast cancer in the univariate logistic regression analysis, which did not reach statistical significance in multivariate logistic regression analysis. However, in the analysis of the age-matched groups of patients, TSHRAb was found to be the only positive determinant of breast cancer. Therefore, we suggest that TSHRAb can be called a positive predictor for the subsequent development of breast cancer. However,

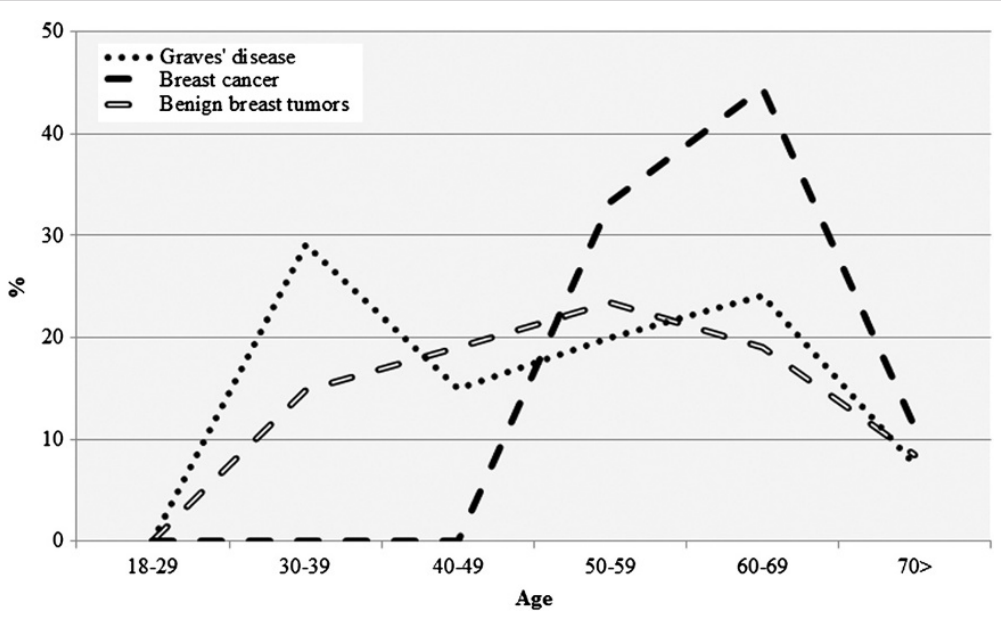

Figure 4 Trends in occurrence of breast cancer, benign breast tumors and Graves' disease. Distribution of breast cancer (BC) or benign breast tumors (BBT) in relation to age intervals and in comparison to Graves' disease, expressed as linear trends. 
Table 5 Summarized previous reports concerning relationship between thyroid diseases and breast cancer or benign breast tumors

\begin{tabular}{|c|c|c|c|c|c|c|c|c|c|c|c|c|c|c|c|}
\hline \multirow[t]{3}{*}{ Parameter } & \multicolumn{15}{|c|}{ [Previously reported data] ( $n=$ number of patients enrolled to study) } \\
\hline & \multicolumn{3}{|c|}{ [3] $(n=150)$} & \multicolumn{3}{|c|}{$[18](n=115)$} & \multicolumn{3}{|c|}{ [34] $(n=61)$} & \multicolumn{3}{|c|}{$[35](n=175)$} & \multicolumn{3}{|c|}{ [36] $(n=48)$} \\
\hline & BC & $\mathrm{C}$ & $\mathbf{p}$ & BC & C & $\mathbf{p}$ & BC & $\mathrm{C}$ & $\mathbf{p}$ & BC & C & $\mathbf{p}$ & $\mathrm{BC}$ & C & $\mathbf{p}$ \\
\hline n & 150 & 100 & - & 66 & 49 & - & 36 & 100 & - & 100 & 75 & - & 26 & 22 & - \\
\hline $\begin{array}{l}\text { Age-yr means } \pm \text { SD } \\
(\text { min-max })\end{array}$ & $63(38-80)$ & age-matched & - & $63.5 \pm 11.8$ & $68.4 \pm 12.8$ & ns & $52.8 \pm 10.2$ & age-matched & - & $63(38-80)$ & - & - & $(30-85)$ & $\begin{array}{l}\text { age- } \\
\text { matched }\end{array}$ & - \\
\hline TSH & $3.12 \pm 1.40$ & $1.46 \pm 0.82$ & ns & $\begin{array}{c}1.77 \\
(0.15-47.9)\end{array}$ & $\begin{array}{c}1.52 \\
(0.45-14.56)\end{array}$ & ns & $1.9 \pm 0.7$ & $1.8 \pm 1.4$ & ns & $4.12 \pm 1.40$ & $1.39 \pm 0.79$ & 0.030 & $\begin{array}{c}1.36 \pm \\
0.63\end{array}$ & $\begin{array}{c}2.41 \pm \\
0.35\end{array}$ & $<0.05$ \\
\hline units & & $\mu l U / m l$ & & & $m / U / d l$ & & & $\mu l U / m l$ & & & $\mu / U / m l$ & & & $\mu \mathrm{U} / \mathrm{ml}$ & \\
\hline $\mathrm{FT}_{4}$ & $2.64 \pm 0.91$ & $1.42 \pm 0.31$ & ns & $\begin{array}{c}15.70 \\
(7.38-22.63)\end{array}$ & $\begin{array}{c}15.19 \\
(10.5-21.5)\end{array}$ & ns & $9.76 \pm 2.73$ & $9.9 \pm 2.4$ & ns & $2.93 \pm 0.57$ & $1.39 \pm 0.21$ & 0.030 & $\begin{array}{c}1.40 \pm \\
1.64\end{array}$ & $\begin{array}{c}1.10 \pm \\
0.83\end{array}$ & $<0.05$ \\
\hline units & & $n g / d l$ & & & $\mathrm{pmol} / \mathrm{dl}$ & & & $\mathrm{pg} / \mathrm{ml}$ & & & $n g / d l$ & & & $n g / d l$ & \\
\hline $\mathrm{FT}_{3}$ & $8.47 \pm 0.75$ & $4.48 \pm 0.75$ & ns & & - & & $3.58 \pm 0.7$ & $3.2 \pm 0.6$ & ns & $\begin{array}{c}7.25 \pm 0 \\
75\end{array}$ & $3.42 \pm 0.91$ & 0.030 & $\begin{array}{c}3.56 \pm \\
3.14\end{array}$ & $\begin{array}{c}2.87 \pm \\
3.12\end{array}$ & $<0.00$ \\
\hline units & & $\mathrm{pmol/l}$ & & & & & & $\mathrm{pg} / \mathrm{ml}$ & & & $\mathrm{pmol} / \mathrm{l}$ & & & $\mathrm{pmol} / \mathrm{ml}$ & \\
\hline $\operatorname{TgAb}$ & $140.92 \pm 21.52$ & $27.75 \pm 7.60$ & ns & $\begin{array}{c}35.80 \\
(26.1-6000.0)\end{array}$ & $\begin{array}{c}27.70 \\
(18.5-298.0)\end{array}$ & $<0.001$ & $12 / 36$ & $12 / 100$ & $\mathrm{p}<0.01$ & & - & & & - & \\
\hline units & & $\mathrm{IU} / \mathrm{ml}$ & & & $\mathrm{kIU} / \mathrm{dl}$ & & Patients' & ratio with positiv & e $\operatorname{Tg} A b$ & & & & & & \\
\hline TPOAb & $105.82 \pm 21.46$ & $23.08 \pm 4.16$ & 0.030 & $\begin{array}{c}6.10 \\
(6.1-871.0)\end{array}$ & $\begin{array}{c}6.10 \\
(6.1-1621.6)\end{array}$ & ns & $12 / 36$ & $8 / 100$ & $\mathrm{p}<0.01$ & $\begin{array}{c}104.57 \pm \\
19.39-\end{array}$ & $\begin{array}{c}24.81 \pm \\
5.16\end{array}$ & 0.030 & & - & \\
\hline units & & $\mathrm{IU} / \mathrm{ml}$ & & & $\mathrm{kIU} / \mathrm{dl}$ & & Patients' r & atio with positive & TPOAb & & $1 \mathrm{U} / \mathrm{ml}$ & & & & \\
\hline Diagnosis & $\mathrm{BC}$ & $\mathrm{C}$ & p & $B C$ & $\mathrm{C}$ & $p$ & & & & - & & & & & \\
\hline Graves' disease & & - & & $0 / 66$ & $0 / 49$ & - & & & & & & & & & \\
\hline AITD & $57 / 150$ & $17 / 100$ & 0.001 & $16 / 66$ & $8 / 49$ & - & & & & & & & & & \\
\hline
\end{tabular}

Summary of the previously reported endocrine and immunological laboratory status in patients with breast cancer (BC) and controls (C); ns, non-significant. 
further prospective research is required on a larger group of patients to determine unquestionably the significance of the above association.

Consequently, neutral TSHR antagonists (ligands inhibiting receptor activation by agonists), such as NIDDKCEB-52, NCGC00242595 and NCGC00229600, could play a potential role in the breast cancer prophylaxis, acting as precursors of drugs preventing from TSHRAb activation in patients with Graves' disease [45]. Monoclonal antibodies, currently used in experimental studies on the medical therapeutic intervention in Graves' disease by vaccination with chemically altered autoantigens, could selectively deplete specific $\mathrm{T}$ lymphocytes subsets and block the T-cell receptor MHC interaction [46]. Additionally, no reports were found assessing the theoretical suppressive effect of blocking subtype of TSHRAb (causing hypothyroidism) on breast cancer and thus such clinical research would be advisable.

As discussed above, reduced iodide concentration, elevated levels of the thyroid hormones and antibodies contributed to an increased risk of breast cancer in previous reports and in our study. However, some authors suggested also the possible impact of breast cancer on the thyroid with the resulting increased level of thyroid hormones and the autoimmune response with the detectable thyroid antibodies [5]. In our series we found shift of about 15-20 years between the primary peak of the diagnosed Graves' disease and the secondary maximal incidence of breast cancer (Figure 4). However, the observed long shift is partially affected by the fact that participants in our study were younger than the general population of patients with Graves' disease, as they were hospitalized due to the more prominent symptoms. Older patients with usually more subtle clinical course of Graves' disease are treated as outpatients [47]. Despite some possible level of bias, we claim that it is the Graves' disease which could contribute to the subsequently observed development of breast cancer.

In conclusion, the strong relationship between Graves' disease and breast cancer is proposed. We suggest that TSHRAb could be described as a positive determinant of breast cancer. The present data call attention to the usefulness of screening for breast cancer in long-term follow-up of patients with autoimmune thyroid disorders, especially of those with Graves' disease. Similarly, screening for autoimmune thyroid disorders should be performed in patients with nodular breast disease. Additionally, the article draws ideas for further research in order to develop targeted treatment for more successful outcome in patients with breast cancer.

\section{Competing interests}

The authors declare that they have no competing interests.

\section{Authors' contributions}

PS, WS, AL \& MKL have made substantial contributions to conception and design of the study. PS and WS were involved in the acquisition of data. PS designed the data analysis program. All authors (PS, WS, AG, AL \& MKL) performed analysis and interpretation of data. PS was involved in drafting the manuscript. MKL revised the draft critically for important intellectual content. AL \& MKL supervised and guided all the steps of preparing the manuscript and gave final approval of the version to be published. All authors read and approved the final manuscript.

\section{Acknowledgements}

The study was supported by the statutory funds No. 503/1-107-03/503-01 and No. 503/1-107-05/503-01 from the Medical University of Lodz.

\section{Author details}

${ }^{1}$ Department of Oncological Endocrinology, Medical University of Lodz, 7/9 Zeligowski St., 90-752, Lodz, Poland. 'Department of Endocrinology and Metabolic Diseases, Medical University of Lodz, Lodz, Poland. ${ }^{3}$ Department of Endocrinology and Metabolic Diseases, Polish Mother's Memorial Hospital, Research Institute, Lodz, Poland. ${ }^{4}$ Current address: Department of Oncological Surgery and Breast Diseases, Polish Mother's Memorial Hospital, Research Institute, Lodz, Poland. ${ }^{5}$ Current address: 1 st Department of Cardiology, Medical University of Warsaw, Warsaw, Poland.

Received: 27 March 2013 Accepted: 5 May 2013

Published: 16 May 2013

\section{References}

1. Dinda S, Sanchez A, Moudgil V: Estrogen-like effects of thyroid hormone on the regulation of tumor suppressor proteins, p53 and retinoblastoma, in breast cancer cells. Oncogene 2002, 21:761-768.

2. Conde I, Paniagua R, Zamora J, Blanquez MJ, Fraile B, Ruiz A, Arenas MI: Influence of thyroid hormone receptors on breast cancer cell proliferation. Ann Oncol 2006, 17:60-64.

3. Turken O, Narln Y, Demlrbas S, Onde ME, Sayan O, Kandemlr EG, Yaylacl M, Ozturk A: Breast cancer in association with thyroid disorders. Breast Cancer Res 2003, 5:R110-R113.

4. Hellevik Al, Asvold BO, Bjøro T, Romundstad PR, Nilsen TI, Vatten LJ: Thyroid function and cancer risk: a prospective population study. Cancer Epidemiol Biomarkers Prev 2009, 18:570-574.

5. Tosovic A, Bondeson AG, Bondeson L, Ericsson UB, Malm J, Manjer J: Prospectively measured triiodothyronine levels are positively associated with breast cancer risk in postmenopausal women. Breast Cancer Res 2010, 12:R33.

6. Siegler JE, Li X, Jones SD, Kandil E: Early-onset breast cancer in a woman with Graves' disease. Int J Clin Exp Med 2012, 5:358-362.

7. Angelousi AG, Anagnostou VK, Stamatakos MK, Georgiopoulos GA, Kontzoglou KC: Mechanisms in endocrinology: primary HT and risk for breast cancer: a systematic review and meta-analysis. Eur J Endocrinol 2012, 166:373-381.

8. Ito K, Maruchi N: Breast cancer in patients with Hashimoto's thyroiditis Lancet 1975, 2:1119-1121.

9. Kapdi JJ, Wolfe JN: Breast cancer relationship to thyroid supplements for hypothyroidism. JAMA 1976, 236:1124-1127.

10. Nelson M, Hercbergs A, Rybicki L, Strome M: Association between development of hypothyroidism and improved survival in patients with head and neck cancer. Arch Otolaryngol Head Neck Surg 2006, 132:1041-1046.

11. Maruchi N, Annegers JF, Kurland LT: Hashimoto's thyroiditis and breast cancer. Mayo Clin Proc 1976, 51:263-265.

12. Hamasaki H, Yoshimi T, Yanai H: A patient with Graves' disease showing only psychiatric symptoms and negativity for both TSH receptor autoantibody and thyroid stimulating antibody. Thyroid Res 2012, 5:19.

13. Oh HJ, Chung JK, Kang JH, Kang WJ, Noh DY, Park IA, Jeong JM, Lee DS, Lee MC: The relationship between expression of the sodium/iodide symporter gene and the status of hormonal receptors in human breast cancer tissue. Cancer Res Treat 2005, 37:247-250.

14. Munoz JM, Gorman CA, Elveback LR, Wentz JR: Incidence of malignant neoplasms of all types of patients with Graves' disease. Arch Intern Med 1978, 138:944-947. 
15. Chen YK, Lin CL, Chang YJ, Cheng FT, Peng CL, Sung FC, Cheng $Y H$, Kao CH: Cancer risk in patients with Graves' disease: A nationwide cohort study. Thyroid. in press.

16. Hardefeldt PJ, Eslick GD, Edirimanne S: Benign thyroid disease is associated with breast cancer: a meta-analysis. Breast Cancer Res Treat 2012, 133:1169-1177.

17. Venturi S: Is there a role for iodine in breast diseases? Breast 2001, 10:379-382.

18. Jiskra J, Límanová Z, Barkmanová J, Smutek D, Friedmannová Z: Autoimmune thyroid diseases in women with breast cancer and colorectal cancer. Physiol Res 2004, 53:693-702.

19. Smyth PP: The thyroid, iodine and breast cancer. Breast Cancer Res 2003, 5:235-238.

20. Giani C, Fierabracci P, Bonacci R, Gigliotti A, Campani D, De Negri F, Cecchetti D, Martino E, Pinchera A: Relationship between breast cance and thyroid disease: relevance of autoimmune thyroid disorders in breast malignancy. J Clin Endocrinol Metab 1996, 81:990-994.

21. Smyth PPA, Shering S, Kilbane MT, Murray MJ, McDermott EWM, Smith DF, O'Higgins NJ: Serum thyroid peroxidase autoantibodies, thyroid volume and outcome in breast cancer. J Clin Endocrinol Metab 1998, 83:2711-2716.

22. Kuijpens JL, Nyklíctek I, Louwman MW, Weetman TA, Pop VJ, Coebergh JW Hypothyroidism might be related to breast cancer in post-menopausal women. Thyroid 2005, 15:1253-1259.

23. Simon MS, Tang MT, Bernstein L, Norman SA, Weiss L, Burkman RT, Daling JR, Deapen D, Folger SG, Malone K, Marchbanks PA, McDonald JA, Strom BL, Wilson HG, Spirtas R: Do thyroid disorders increase the risk of breast cancer? Cancer Epidemiol Biomarkers Prev 2002, 11:1574-1578.

24. Latif R, Morshed SA, Zaidi M, Davies TF: The thyroid-stimulating hormone receptor: impact of thyroid-stimulating hormone and thyroid-stimulating hormone receptor antibodies on multimerization, cleavage, and signaling. Endocrinol Metab Clin North Am 2009, 38:319-341.

25. Zygmunt A, Adamczewski Z, Wojciechowska-Durczyńska K, CyniakMagierska A, Krawczyk-Rusiecka K, Zygmunt A, Karbownik-Lewińska M, Lewiński A: Evaluation of efficacy of iodine prophylaxis in Poland based on the examination of schoolchildren living in Opoczno Town (Lodz Voivodship). Thyroid Res 2012, 5:23.

26. Mittra I, Perrin J, Kumaoka S: Thyroid and other autoantibodies in British and Japanese women: an epidemiological study of breast cancer. BMJ 1976, 1:257-259.

27. Kilbane MT, Ajjan RA, Weetman AP, Dwyer R, McDermott EW, O'Higgins NJ, Smyth PP: Tissue iodine content and serum-mediated 1251 uptake-blocking activity in breast cancer. J Clin Endocrinol Metab 2000, $85: 1245-1250$

28. Beyer SJ, Jimenez RE, Shapiro CL, Cho JY, Jhiang SM: Do cell surface trafficking impairments account for variable cell surface sodium iodide symporter levels in breast cancer? Breast Cancer Res Treat 2009, 115:205-212.

29. Daniels $\mathrm{GH}$, Haber DA: Will radioiodine be useful in treatment of breast cancer? Nat Med 2000, 6:859-860

30. Boelaert K, Franklyn JA: Sodium iodide symporter: a novel strategy to target breast, prostate, and other cancers? Lancet 2003, 361:796-797.

31. Dumont JE, Maenhaut C: Growth factors controlling the thyroid gland. Baillieres Clin Endocrinol Metabol 1991, 5:727-753.

32. Fernández-Soto ML, Jovanovic LG, González-Jiménez A, Lobón-Hernández JA, Escobar-Jiménez F, López-Cózar LN, Barredo-Acedo F, Campos-Pastor MM, López-Medina JA: Thyroid function during pregnancy and the postpartum period: iodine metabolism and disease states. Endocr Pract 1998, 4:97-105.

33. Karbownik-Lewińska M, Kokoszko-Bilska A: Oxidative damage to macromolecules in the thyroid - experimental evidence. Thyroid Res 2012, 5:25.

34. Giustarini E, Pinchera A, Fierabracci P, Roncella M, Fustaino L, Mammoli C, Giani $C$ : Thyroid autoimmunity in patients with malignant and benign breast diseases before surgery. Eur J Endocrinol 2006, 154:645-649.

35. Ali A, Mir MR, Bashir S, Hassan T, Bhat SA: Relationship between the levels of Serum Thyroid Hormones and the Risk of Breast Cancer. J Biol Agr Healthc 2011, 2:56-60.

36. Saraiva PP, Figueiredo NB, Padovani CR, Brentani MM, Nogueira CR: Profile of thyroid hormones in breast cancer patients. Braz J Med Biol Res 2005, 38:761-765
37. Smyth PPA: Autoimmune thyroid disease and breast cancer: a chance association. J Endocrinol Invest 2000, 23:42-43.

38. Belkadi A, Jacques C, Savagner F, Malthièry Y: Phylogenetic analysis of the human thyroglobulin regions. Thyroid Res 2012, 5:3.

39. Cahoon EK, Rozhko A, Hatch M, Polyanskaya O, Ostroumova E, Tang M, Nadirov E, Yauseyenka V, Savasteeva I, McConnell RJ, Pfeiffer RM, Brenner AV: Factors associated with serum thyroglobulin levels in a population living in Belarus. Clin Endocrinol (Oxf) 2012. in press.

40. Molleston JP, Mellman W, Narkewicz MR, Balistreri WF, Gonzalez-Peralta RP Jonas MM, Lobritto SJ, Mohan P, Murray KF, Njoku D, Rosenthal P, Barton BA, Talor MV, Cheng I, Schwarz KB, Haber BA, for the PEDS-C Clinical Research Network: Autoantibodies and Autoimmune Disease During Treatment of Children With Chronic Hepatitis C. J Pediatr Gastroenterol Nutr 2013, 56:304-310

41. Hill OW: Thyroglobulin antibodies in 1,297 patients without thyroid disease. Br Med J 1961, 5242:1793-1796.

42. Tunbridge WM, Vanderpump MP: Population screening for autoimmune thyroid disease. Endocrinol Metab Clin North Am 2000, 29:239-253.

43. Mizia-Stec K, Zych F, Widala E: Mastopathy and simple goiter-mutual relationships. Przegl Lek 1998, 55:250-258.

44. Kopp P: The TSH receptor and its role in thyroid disease. Cell Mol Life SCi 2001, 58:1301-1322

45. Gershengorn MC, Neumann S: Update in TSH receptor agonists and antagonists. J Clin Endocrinol Metab 2012, 97:4287-4292.

46. Swain M, Swain T, Mohanty BK: Autoimmune thyroid disorders-An update. Indian J Clin Biochem 2005, 20:9-17.

47. Gesing A, Lewiński A, Karbownik-Lewińska M: The thyroid gland and the process of aging; what is new? Thyroid Res 2012, 5:16.

doi:10.1186/1756-6614-6-8

Cite this article as: Szychta et al.: TSH receptor antibodies have predictive value for breast cancer - retrospective analysis. Thyroid Research 2013 6:8.

\section{Submit your next manuscript to BioMed Central and take full advantage of:}

- Convenient online submission

- Thorough peer review

- No space constraints or color figure charges

- Immediate publication on acceptance

- Inclusion in PubMed, CAS, Scopus and Google Scholar

- Research which is freely available for redistribution 